\title{
Adjuvant HIPEC for gastric cancer
}

\author{
Paul H. Sugarbaker ${ }^{1}$, Kurt Van der Speeten ${ }^{2}$ \\ ${ }^{1}$ MedStar Washington Hospital Center, Washington, DC, USA; ${ }^{2}$ Department of Surgery, Hospital Oost-Limburg, Genk, Belgium \\ Correspondence to: Paul H. Sugarbaker, MD. MedStar Washington Hospital Center, Washington, DC, USA. Email: Paul.Sugarbaker@outlook.com; \\ Kurt Van der Speeten. Department of Surgery, Hospital Oost-Limburg, Genk, Belgium. Email: Kurt.Vanderspeeten@zol.be. \\ Comment on: Reutovich MY, Krasko OV, Sukonko OG. Hyperthermic intraperitoneal chemotherapy in prevention of gastric cancer metachronous \\ peritoneal metastases: a systematic review. J Gastrointest Oncol 2021;12:S5-17.
}

Submitted Dec 16, 2020. Accepted for publication Mar 16, 2021.

doi: 10.21037/jgo-2020-08

View this article at: http://dx.doi.org/10.21037/jgo-2020-08

The first section of our Focused Issue concerns peritoneal metastases (PM) from gastric cancer. Perhaps the most likely success from HIPEC or EPIC is adjuvant treatment of gastric cancer at high risk for subsequent surgical treatment failure at the resection site or on peritoneal surfaces (1). This attempt to eradicate single gastric cancer cells that enter the peritoneal space prior to or at the time of gastric cancer resection was initiated at Tottori University, Yonago, Japan as early as 1988 (2). Data on adjuvant HIPEC for resected gastric cancer from Belarus highlight the inevitable difficulty of treating a systemic disease with a regional chemotherapy. The RCT using HIPEC with cisplatin and doxorubicin did not show an overall survival benefit $(\mathrm{P}=0.2)$. However, early occurrence of $\mathrm{PM}$ was reduced with a progression-free survival at 4 years in $19.6 \%$ of the control group as compared to $47.1 \%$ of the group treated with HIPEC $(\mathrm{P}<0.001)$. Reutovich concludes by calling for studies that would utilize HIPEC upfront in the timeline of the disease to prevent PM plus adjuvant systemic chemotherapy to treat systemic disease. As such the authors rightfully point out that the way forward is an intelligent combined locoregional and systemic treatment. Not surprisingly, the data from Belarus shows marked local-regional effects that translate into a small survival benefit. In a repeat study, quality of life parameters are necessary to show that prevention of PM results in fewer adverse events from loss of intestinal function. We asked Mihail Reutovich to send disease-free and overall survival curves for the 123 patients with gastric cancer randomized \pm HIPEC. Usually, the survival curves are most interesting and tell a story about regional chemotherapy. Delay in the recurrence of PM shows an impressive separation of the HIPEC and no HIPEC groups for disease-free survival (Figure 1A). Because PM are not often the only site of metastases, the overall survival is not significant (Figure 1B).
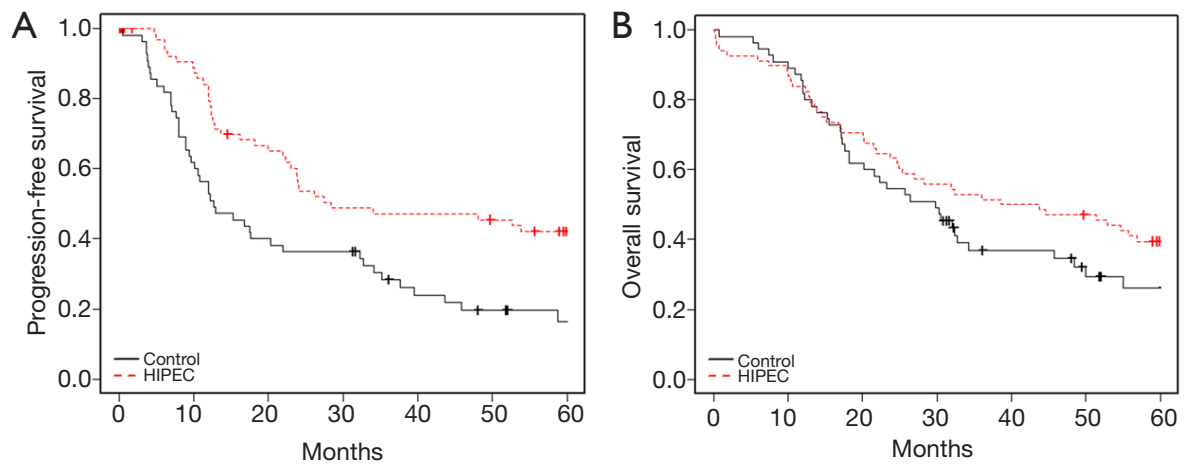

Figure 1 Progression-free and overall survival for gastric cancer. (A) Progression-free survival in 123 gastric cancer patients in HIPEC and control groups $(\mathrm{P}<0.001)$. (B) Overall survival in 123 gastric cancer patients in HIPEC and control groups $(\mathrm{P}=0.2)$. 


\section{Acknowledgments}

Funding: None.

\section{Footnote}

Provenance and Peer Review: This article was commissioned by the editorial office, Fournal of Gastrointestinal Oncology for the focused issue "Intraperitoneal Chemotherapy for Peritoneal Metastases: HIPEC, EPIC, NIPEC, PIPAC and More". The article did not undergo external peer review.

Conflicts of Interest: Both authors have completed the ICMJE uniform disclosure form (available at http:// dx.doi.org/10.21037/jgo-2020-08). The focused issue was sponsored by the Peritoneal Surface Oncology Group International (PSOGI). Drs. PHS and KVDS served as the unpaid Guest Editors of the focused issue. The authors have no other conflicts of interest to declare.

Ethical Statement: The authors are accountable for all aspects of the work in ensuring that questions related to the accuracy or integrity of any part of the work are appropriately investigated and resolved.

Open Access Statement: This is an Open Access article distributed in accordance with the Creative Commons Attribution-NonCommercial-NoDerivs 4.0 International License (CC BY-NC-ND 4.0), which permits the noncommercial replication and distribution of the article with the strict proviso that no changes or edits are made and the original work is properly cited (including links to both the formal publication through the relevant DOI and the license). See: https://creativecommons.org/licenses/by-nc-nd/4.0/.

\section{References}

1. Reutovich MY, Krasko OV, Sukonko OG. Hyperthermic intraperitoneal chemotherapy in prevention of gastric cancer metachronous peritoneal metastases: a systematic review. J Gastrointest Oncol 2021;12:S5-17.

2. Koga S, Hamazoe R, Maeta M, et al. Prophylactic therapy for peritoneal recurrence of gastric cancer by continuous hyperthermic peritoneal perfusion with mitomycin C. Cancer 1988;61:232-7.

Cite this article as: Sugarbaker PH, Van der Speeten K. Adjuvant HIPEC for gastric cancer. J Gastrointest Oncol 2021;12(Suppl 1):S18-S19. doi: 10.21037/jgo-2020-08 